\title{
Clinton's green think-tank under a cloud
}

Chicago. A new alliance between scientists and the private sector can solve some of America's most intractable environmental problems, Bruce Babbitt, the US interior secretary, told the President's Council on Sustainable Development last week when it visited the mid-West to see for itself how such problems are afflicting the country's heartland.

But the high-powered council, established last year by President Bill Clinton to help him to develop new and convincing environmental policies, was starkly confronted with the limitations of the Babbitt approach on the banks of Lake Michigan.

In particular, it faced the clear dichotomy between the shiny statements it has been polishing in Washington, and the dirty reality of life for those left to rot on what is known as the 'rustbelt'.

The Chicago meeting was the second such mission for the 25 -strong council, made up of cabinet members, chief executives of leading industrial companies and the heads of the main environmental pressure groups. The council has drafted a 'vision statement' and 15 proposed principles, and is to report to the president in a year's time.

After field trips to Chicago's decrepit south side and to the steel town of Gary, Indiana, Jonathan Lash, co-chairman of the council and president of the World Resources Institute, said that the trips had stimulated "a very strong reaction" in council members. "A lot of people saw and heard things they hadn't seen before."

Lash says that the new experiences con- cern "the whole question of brownfields and environmental equity". He was referring to the stalemate over the fate of disused industrial land that is adversely affecting people's lives, particularly those of the black people who live next door to it.

Gary was once the home of the world's largest integrated steel mill. The council's visit was intended to see local "ecological restoration activities", including the 20-year-old 15,000-acre Indiana Dunes National Lake Shore. This is the world's first national park on industrial land, and is a key site in the development of ecological science.

But the council heard of what Carlos Tolliver, a local activist, called "a city under economic and environmental siege". His description was hard to dispute at a public meeting held beneath the pall of thick black smoke from a local tyre dump, where 70,000 tonnes of rubber had been burning out of control for three days.

More landfill dumps are planned for Gary, where a quarter of households have an income of less than $\$ 10,000$ a year, and the city council is keen for any development it can get, sustainable or otherwise.

If there is a traditional US model for resource management, it is one in which environmentalists fight industrialists or landowners in the courts until an expensive stalemate is reached. Babbitt thinks that

\section{EPA pledges more long-term research}

Chicago. The US Environmental Protection Agency (EPA) has announced plans to allocate half of its annual research budget to long-term research, to ensure that a greater proportion of its research funds is made available to universities and to improve standards of peer review.

In addition, the agency's laboratories will be reorganized into four sections dealing with risk management, risk assessment, exposure hazards, and health and environment issues.

The reforms were announced last week by Carol Browner, the EPA administrator, to a meeting of the President's Council of Sustainable Development in Chicago. At present, the bulk of the EPA's widely criticized research programme is short-term work needed to support the $\$ 7.2$-billion agency's regulatory function.

Browner hopes that the changes will head off calls for a free-standing National Institute for the Environment (NIE) aimed at raising the standards of federally funded environmental research.
The EPA was founded in the early 1970 s as an amalgam of existing regulatory agencies, but has never established a signifi cant track record in supporting environmen tal research. Its intramural programme is split up between a large number of labora tories, and 90 per cent of its \$350-million extramural programme is spent on routine contract research.

The reorganization of EPA's laborato ries is intended to address the problems caused by fragmentation. But the largest changes will be those needed to achieve a 50:50 balance between short-term and longterm research; Neil Dobbs of the Campaign for an NIE claims the present balance is about 85:15 in favour of regulatory work.

The agency is promising to raise its annual funding for competitive, peerreviewed, investigator-initiated grants from $\$ 20$ million to $\$ 100$ million annually, although no timescale for achieving this has been announced, nor was an EPA spokesman able to say where the money would come from.

Colin Macilwain

\section{IMAGE UNAVAILABLE FOR COPYRIGHT REASONS}

